\title{
PEMANFAATAN FITOPLANKTON SEBAGAI BIOINDIKATOR BERBAGAI JENIS POLUTAN DI PERAIRAN INTERTIDAL KOTA KUPANG
}

\author{
Esau D. N. Haninuna1 ${ }^{1}$ Ricky Gimin², Ludji M. Riwu Kaho³ \\ Program Studi IImu Lingkungan, Program Pascasarjana, Universitas Nusa Cendana, email: \\ esau_haninuna@yahoo.co.id
}

\begin{abstract}
ABSTRAK
Penelitian ini dilaksanakan selama tiga bulan terhitung dari bulan Desember 2014 sampai Februari 2015 dengan tujuanmengetahui perbedaan jenis polutan yang dominan antar lokasi di Teluk Kupang, mengetahui korelasi antara kandungan Nutrien $\left(\mathrm{NO}_{3}\right), \mathrm{PO}_{4}$, minyak dan POM serta mutu kualitas air lainnya dengan kelimpahan, keanekaragaman, kemerataan jenis dan dominansi fitoplankton, mengetahui perbedaan kelimpahan, keanekaragaman, kemerataan jenis dan dominansi fitoplankton berdasarkan jenis polutan. Hasil penelitian memperlihatkan bahwa jenis fitoplankton yang ditemukan di Teluk Kupang (Tenau, Kampung Solor, Oeba dan Lasiana)terdiri dari 32 jenis, tergolong ke dalam kelas Diatom 27 genus dan Kelas Dinoflagellta 5 genus.Spesies yang paling banyak ditemui selama penelitian adalah dari genus Pelagothrix, spesies ini termasuk dalam Kelas Diatom.Nilai kelimpahan fitoplankton tertinggi di Oeba, dan terendah di Tenau, nilai keanekaragaman fitoplankton tertinggi terdapat di Tenau dan terendah terdapat di Oeba, nilai kemerataan jenis fitoplankton tertinggi di Tenau dan yang terendah di Oeba, sedangkan nilai dominansi fitoplankton tertinggi di Oeba dan terendah di Tenau.Hasil Analisis Sidik Ragam menunjukan bahwa ada perbedaan jenis polutan yang dominan antar lokasi di Teluk Kupang dan ada perbedaan kelimpahan, keanekaragaman, kemerataan jenis dan dominansi berdasarkan jenis polutan dan Hasil Analisis Person menunjukan bahwa ada hubungan yang kuat antara kandungan Nutrien $\left(\mathrm{NO}_{3}\right), \mathrm{PO}_{4}$, minyak dan POM serta mutu kualitas air lainnya dengan kelimpahan, keanekaragaman, kemerataan jenis dan dominansi fitoplankton di setiap lokasi penelitian. Berdasarkan konsentrasi nitrat, fosfat, minyak dan POM memperlihatkan bahwa perairan Intertidal sekitar Teluk Kupang termasuk kategori tercemar berat.
\end{abstract}

Kata Kunci : Jenis polutan, bioindikator perairan, perairan intertidal, fitoplankton.

\section{PENDAHULUAN}

Teluk Kupang merupakan wilayah perairan yang terletak di ujung barat Pulau Timor Nusa Tenggara Timur dan merupakan cakupan wilayah dari Kabupaten Kupang dan Kota Kupang. Wilayah ini memiliki berbagai ekosistem di dalamnya seperti ekosistem mangrove, ekosistem terumbu karang dan ekosistem padang lamun. Adanya ketiga ekosistem tersebut maka dapat menjadikan wilayah ini menjadi wilayah yang berpotensi akan sumberdaya perikanan dan kelautan. Dengan melihat adanya hal demikian, maka pada Tahun 1993, berdasarkan SK Menhut No. 18/ Kpts-II/ 1993, wilayah ini ditetapkan sebagai TWAL Teluk Kupang dengan luas wilayah sebesar 50.000 ha. Selain menjadikan wilayah ini berpotensi, ketiga ekosistem tersebut juga merupakan ekosistem yang rentan terhadap berbagai gangguan aktivitas manusia.

Seiring dengan meningkatnya aktivitas antropogenik di sepanjang pantai teluk kupang, terutama pantai bagian selatan, telah mengakibatkan berbagai dampak negatif. Wilayah teluk kupang bagian selatan berbatasan dengan Kota Kupang dan bagian utara wilayah teluk kupang berbatasan dengan Kabupaten Kupang. Kegiatan-kegiatan yang berada di bagian selatan teluk kupang dapat berupa kegiatan pelabuhan, pemukiman, perhotelan, aktivitas pasar dan lain-lain. Sedangkan kegiatankegiatan yang dilakukan di bagian utara Teluk Kupang dapat berupa kegiatan 
pariwisata, persawahan, penebangan liar mangrove dan lain-lain. Dengan semakin meningkatnya kegiatan-kegiatan ini sebagai akibat dari meningkatnya jumlah penduduk dan kegiatan perekonomian maka timbul berbagai dampak negatif di perairan ini.

Aktivitas-aktivitas tersebut di atas, baik secara langsung maupun tidak langsung akan berdampak terhadap keseimbangan ekosistem di kawasan perairan tersebut. Hal ini disebabkan karena masuknya limbah organik dan anorganik (sampah) dari berbagai kegiatan manusia sehingga menimbulkan pencemaran dan menyebabkan penurunan kualitas lingkungan perairan dan kemudian dapat mempengaruhi kehidupan biota perairan.Hasil penelitian Rusydi, dkk (2010) yang melakukan penelitian di perairan Kecamatan Kupang Barat pada 5 stasiun pengamatan ditemukan presentase penutupan karang berkisar antara 10,36 - 20,12\% tergolong kategori sangat rendah, sedangkan di perairan Pulau Semau yang diteliti pada 5 stasiun ditemukan presentase penutupan karang keras antara 0,20 $-35,22 \%$ tergolong kategori sangat rendah sampai sedang.Sine (2012), juga melakukan pengamatan kondisi terumbu karang di Teluk Kupang pada 6 lokasi (Pertamina Bolok, Pelabuhan Tenau, Batu Kepala, Oesapa, Pulau Kera bagian Timur dan bagian Selatan) ditemukan presentase penutupan karang keras antara 4,0 - 50 $\%$ dengan rata-rata 33,33 \% tergolong kategori sedang.Bait (2011), juga mengemukakan bahwa jenis mangrove yang ditemukan di Bipolo ada 11 jenis dan jenis yang memiliki kerapatan pohon tertinggi adalah Lumnitzera racemosa (Combretaceae). Hasil analisis indeks keragaman $\left(\mathrm{H}^{\prime}\right)$ pada tingkat pohon pada 6 stasiun pengamatan di desa Bipolo berada pada kisaran 0,79-3,52 tergolong kategori sangat buruk, sedang sampai baik.Jumini (2011), juga melaporkan bahwa hasil analisis nilai Indeks Keragaman $\left(\mathrm{H}^{\prime}\right)$ dari 3 jenis lamun (Enhalus acoroides, Cymodocea rotundata dan Syringodium isoetifolium) yang diteliti di Tablolong, Kabupaten Kupang, nilai $\mathrm{H}^{\prime}$ berkisar antara 1,0982,160. Begitu pula di Paradiso nilai H'dari
Cymodocea rotundata dan Syringodium isoetifolium berada pada kisaran 1,2801,506. Artinya keanekaragaman jenis lamun pada kedua lokasi berada pada kategori sedang, produktivitas cukup, kondisi ekosistem cukup seimbang, dan tekanan ekologis sedang. Mas'ulah (2011), juga menemukan bahwa jenis lamun di desa Bolok terdiri atas Halodule uninervis, H. pinifolia, Cymodocea rotundata dan Syringodium isoetifolium termasuk famili Potamogetonaceae, dan Enhalus acoroides dari famili Hydrocharitaceae. Nilai rata-rata indeks keragaman $\left(\mathrm{H}^{\prime}\right)$ lamun sebesar 0,844. Nilai ini menunjukkan keanekaragaman jenis lamun rendah, miskin dan produktivitas rendah yang mengindikasikan kondisi ekosistem lamun di desa Bolok berada dalam kondisi tertekan. Kondisi-kondisi tersebut di atas sangat erat kaitannya dengan berbagai aktivitas yang dilakukan oleh masyarakat di sekitar wilayah Teluk Kupang.

Penelitian ini bertujuan untuk :

1. Mengetahui perbedaan jenis polutan yang dominan antar lokasi di Teluk Kupang.

2. Mengetahui korelasi antara kandungan Nutrien $\left(\mathrm{NO}_{3}\right), \mathrm{PO}_{4}$, minyak dan POM serta mutu kualitas air lainnya dengan kelimpahan, keanekaragaman, kemerataan jenis dan dominansi fitoplankton.

3. Mengetahui perbedaan kelimpahan, keanekaragaman, kemerataan jenis dan dominansi fitoplankton berdasarkan jenis polutan

\section{METODE PENELITIAN}

\subsection{Waktu dan Tempat}

Penelitian ini dilaksanakan pada bulan Desember 2014 s/ d Februari 2015 di perairan Intertidal Teluk Kupang pada empat lokasi yang berbeda yaitu perairan intertidal Tenau, perairan intertidal Kampung Solor, perairan intertidal Oeba dan perairan intertidal Lasiana Kota Kupang. Identifikasi dan analisis sampel dilakukan di Laboratorium Fakultas Sains dan Teknik Undana dan Fakultas Kelautan dan Perikanan Undana. 


\subsection{Alat dan Bahan}

Peralatan yang digunakan dilapangan adalah: GPS, ember plastik volume 15 liter, plankton net no.50, vandorn, botol sampel volume $30 \mathrm{ml}$ untuk sampel fitoplankton, botol untuk sampel air volume $500 \mathrm{ml}$, thermometer, kertas $\mathrm{pH}$, hand refraktometer, ice box, dan peralatan tulis. Peralatan di laboratorium yang digunakan adalah mikroskop, objek glass, pipet tetes, cover glass, spektrofotometer, erlenmeyer dan buku-buku identifikasi fitoplankton. Bahan yang digunakan antara lainakuades dan larutan lugol 5\% untuk pengawet sampel fitoplankton.

\subsection{Metode}

Metode yang digunakan dalam penelitian ini adalah metode survei, data yang dikumpulkan berupa data kualitas air baik yang diukur dan diamati di lapangan atau yang dianalisis di laboratorium. Selanjutnya data yang diperoleh ditabulasikan ke dalam bentuk tabel. Data parameter kualitas air dianalisis secara deskriptif. Sedangkan untuk melihat hubungan antara beberapa parameter kualitas air dengan fitoplankton dianalisis menggunakan:

1. Analisis Sidik Ragam (Anova)

2. Analisis Koefisien Korelasi Pearson (r) antar parameter (parameter fisik, kimia terhadap fitoplankton).

\subsection{Lokasi Pengambilan Sampel Lokasi selama penelitian dibagi menjadi 4 lokasi yang terbentuk antara koordinat LSs/ d koordinat BT.}

Tabel 1 Tabel titik Pengambilan Sampel secara Geografis

\begin{tabular}{|c|c|c|}
\hline Lokasi & Titik Sampling & Karakteristik Lokasi \\
\hline Tenau & $\begin{array}{l}\text { 1. } 10^{\circ} 11^{\prime} 47.13^{\prime \prime L S} \\
123^{\circ} 31^{\prime} 33.41^{\prime \prime B T} \\
2.10^{\circ} 11^{\prime} 44.89^{\prime \prime L S} \\
123^{\circ} 31^{\prime} 33.30^{\prime \prime} \mathrm{BT} \\
3.10^{\circ} 11^{\prime} 42.61^{\prime \prime L S} \\
123^{\circ} 31^{\prime} 33.25^{\prime \prime B T} \\
4.10^{\circ} 11^{\prime} 40.19^{\prime \prime L S} \\
123^{\circ} 31^{\prime} 33.05^{\prime \prime B T} \\
5.10^{\circ} 11^{\prime} 38.01^{\prime \prime L S} \\
123^{\circ} 31^{\prime} 33.02^{\prime \prime B T}\end{array}$ & $\begin{array}{l}\text { Aktivitas-aktivitas yang ada di pelabuhan tenau adalah pelabuhan dan } \\
\text { pemukiman. Salah satu aktivitas yang mempengaruhi perkembangan } \\
\text { fitoplankton adalah aktifitas kapal penumpang dan kapal barang. } \\
\text { Aktivitas pelabuhan memberikan kontribusi limbah air balast, minyak } \\
\text { dari kapal-kapal, peletakan jangkar, dan bersih-bersih kapal yang } \\
\text { dapat mempengaruhi komponen fisik-kimia air laut dan dapat } \\
\text { mempengaruhi perkembangan fitoplankton }\end{array}$ \\
\hline $\begin{array}{l}\text { Kampu } \\
\text { ng } \\
\text { Solor }\end{array}$ & $\begin{array}{l}1 . \quad 10^{\circ} 9^{\prime} 37.39 " \mathrm{LS} \\
123^{\circ} 34^{\prime} 35.75^{\prime \prime B T} \\
2 . \quad 10^{\circ} 9^{\prime} 36.72 " \mathrm{LS} \\
123^{\circ} 34^{\prime} 36.63^{\prime \prime} \mathrm{BT} \\
3 . \quad 10^{\circ} 9^{\prime} 36.09^{\prime \prime L S} \\
123^{\circ} 34^{\prime} 37.50^{\prime \prime} \mathrm{BT} \\
4 . \quad 10^{\circ} 9^{\prime} 35.51 " \mathrm{LS} \\
123^{\circ} 34^{\prime} 38.44^{\prime \prime B T} \\
5 . \quad 10^{\circ} 9^{\prime} 34.95^{\prime \prime L S} \\
123^{\circ} 34^{\prime} 39.52^{\prime \prime} \mathrm{BT}\end{array}$ & $\begin{array}{l}\text { Aktivitas-aktivitas yang ada di Kampung Solor adalah pemukiman. Di } \\
\text { sepanjang pantai Kampung Solor terdapat pemukiman yang cukup } \\
\text { padat, dimana pemukiman ini secara langsung maupun tidak langsung } \\
\text { telah memberikan sumbangan limbah berupa limbah rumah tangga. } \\
\text { Sumbangan limbah rumah tangga ini akan mempengaruhi terhadap } \\
\text { perkembangan fitoplankton dan juga dapat mempengaruhi komponen } \\
\text { fisik-kimia air laut }\end{array}$ \\
\hline Oeba & 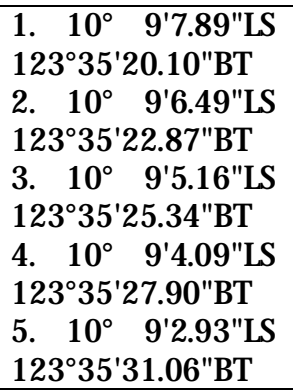 & $\begin{array}{l}\text { Aktivitas-aktivitas yang ada di pantai Oeba adalah industri ikan, } \\
\text { pelabuhan, dan pemukiman. Aktivitas-aktivitas ini dapat } \\
\text { mempengaruhi komponen fisik-kimia air laut sehingga dapat } \\
\text { mempengaruhi perkembangan fitoplankton }\end{array}$ \\
\hline $\begin{array}{l}\text { Lasian } \\
\text { a }\end{array}$ & $\begin{array}{l}\text { 1. } 10^{\circ} 7^{\prime} 47.68^{\prime \prime} \mathrm{LS} \\
123^{\circ} 39^{\prime} 29.07^{\prime \prime} \mathrm{BT} \\
\text { 2. } 10^{\circ} 7^{\prime} 43.47^{\prime \prime} \mathrm{LS} \\
123^{\circ} 39^{\prime} 38.80^{\prime \prime} \mathrm{BT}\end{array}$ & $\begin{array}{l}\text { Aktivitas-aktivitas yang ada di pantai Lasiana adalah pariwisata dan } \\
\text { berdagang di lokasi pariwisata. Aktivitas pariwisata dan berdagang di } \\
\text { lokasi ini dapat merusak habitat yang ada di pantai dengan membuang } \\
\text { sampah sembarangan dan menginjak-injak substrat yang ada, }\end{array}$ \\
\hline
\end{tabular}




\begin{tabular}{|c|c|c|}
\hline Lokasi & Titik Sampling & Karakteristik Lokasi \\
\hline & $\begin{array}{l}\text { 3. } 10^{\circ} 7^{\prime} 39.65^{\prime \prime L S} \\
123^{\circ} 39^{\prime} 48.41^{\prime \prime} \mathrm{BT} \\
4.10^{\circ} 77^{\circ} 37.00^{\prime \prime L S} \\
123^{\circ} 39^{\prime} 57.52^{\prime \prime} \mathrm{BT} \\
5.10^{\circ} 77^{\prime} 34.24 \text { "LS } \\
123^{\circ} 40^{\prime} 68.80^{\prime \prime} \mathrm{BT}\end{array}$ & $\begin{array}{l}\text { sehingga mengganggu biota yang hidup dan menetap di atas substrat } \\
\text { atau di dalamnya. Aktivitas-aktivitas ini dapat mempengaruhi } \\
\text { komponen fisik-kimia air laut sehingga dapat mempengaruhi } \\
\text { perkembangan fitoplankton }\end{array}$ \\
\hline
\end{tabular}

\subsection{Prosedur Pengambilan Sampel Air}

Pengambilan sampel air dilakukan di permukaan sampai botol terisi penuh.Sampel air dimasukkan ke dalam botol sampel dengan volume 500 $\mathrm{mL}$ untuk menganalisis kandungan nitrat $\left(\mathrm{No}_{3}\right)$, fosfat $\left(\mathrm{PO}_{4}\right)$, kandungan minyakdan POM. Setelah itu botol sampel dimasukan kedalam cool box yang telah diberi es batu untuk dibawa ke Laboratorium Kimia Fakultas Sains dan Teknik dan Laboratorium Fakultas Kelautan dan Perikanan Universitas Nusa Cendana Kupang untuk dianalisis.

\subsection{Prosedur Pengambilan Sampel Fitoplankton}

Pengambilan sampel fitoplankton dilakukan sebanyak 5 titik, dengan jarak setiap titik 100 meter pada daerah Intertidal. Pengambilan sampel fitoplankton dilakukan secara vertikal dengan kedalaman $50 \mathrm{~cm}$ dengan menggunakan Vandorn ukuran $10 \mathrm{~L}$ untuk setiap titik pada masing-masing lokasi penelitian. Sampel air fitoplankton dilakukan penyaringan dengan plankton net dengan ukuran mesh size $50 \mu \mathrm{m}$ sebanyak $50 \mathrm{~L}$, setelah itu air yang tersaring dimasukkan ke dalam botol sampel Volume $30 \mathrm{~mL}$ dan diawetkan dengan menggunakan cairan lugol 5\% sampai berwarna kekuning kuningan seperti teh. Setelah itu botol sampel dimasukan kedalam cool box yang telah diberi es batu untuk dibawa ke Laboratorium Fakultas Kelautan dan Perikanan Undana untuk dianalisis dan diidentifikasi. Analisis fitoplankton dilakukan dengan cara mengamati $1 \mathrm{~mL}$ sampel air di counting chamber menggunakan mikroskop binokuler dengan pembesaran 10x10. Fitoplankton yang ditemukan setelah itu diidentifikasi dengan menggunakan buku identifikasi plankton Yamaji (1984) dan Sachlan (1982).

Analisis data dilakukan dengan beberapa indeks yaitu:

1. Kelimpahan fitoplankton

Selanjutnya perhitungan kepadatan fitoplankton dapat dilakukan dengan mengikuti petunjuk Romimohtarto (2007) sebagai berikut :

$$
\mathrm{N}=-\underline{1}
$$

Keterangan :

$\mathrm{N}$ = Jumlah plankton (individu / l)

$\mathrm{n} \quad$ =jumlah sel yang dihitung dalam

$\mathrm{m}$ tetes

$\mathrm{s} \quad=$ volume contoh dengan

pengawetnya (100 ml)

$\mathrm{m}$ =Jumlah tetes contoh yang

diperiksa (20 tetes)

a $=$ volume tiap tetes contoh $(0,05$

$\mathrm{ml})$

$\mathrm{V}=$ volume air tersaring (50 l)

2. Indeks Keanekaragaman

Indeks Keanekaragaman dapat dilakukan dengan menggunakan rumus Indeks Shannon-Wiener (Basmi, 1999) berikut ini :

$$
\mathrm{H}=-\sum_{\mathrm{i}=1}^{\mathrm{S}}(\mathrm{pi})(\ln \mathrm{pi})
$$

Dimana :

$$
\begin{array}{ll}
\mathrm{Pi} & =\sum \text { ni/ N } \\
\mathrm{H} & =\text { Indeks keanekaragaman } \\
\mathrm{Shannon} & \text { - Wiener } \\
\mathrm{S} & =\text { Banyaknya jenis } \\
\mathrm{Pi} & =\text { Jumlah individu suatu } \\
\mathrm{Pi} & \text { = Jumlah individujenis ke-i } \\
\text { spesies total seluruh spesies } \\
\mathrm{ni} \quad \text { Jumlah total individu }
\end{array}
$$

Kriteria :

$\mathrm{H}^{\prime}<1=$ komunitas biota tidak stabil atau kualitas air tercemar berat, $1<\mathrm{H}^{\prime}<3=$ stabilitas komunitas biota sedang atau kualitas air tercemar sedang, 
$\mathrm{H}^{\prime}>3=$ stabilitas komunitas biota dalam kondisi prima (stabil) atau kualitas air bersih

3. Perhitungan Kemerataan Jenis

$$
\begin{aligned}
& \text { Kemerataan Jenis adalah dihitung } \\
& \text { menggunakan rumus yang } \\
& \text { dikemukaan oleh Pielou's Evenness } \\
& \text { (J') (Basmi, 1999) : } \\
& \mathrm{J}=\frac{\mathrm{H}^{\prime}}{\log _{2} \mathrm{~S}} \\
& \text { Dimana, } \\
& \mathrm{J}=\text { Indeks Kemerataan Jenis } \\
& \mathrm{H}^{\prime} \text { = Indeks keanekaragaman } \\
& \mathrm{s} \quad=\text { Jumlah Jenis fitoplankton } \\
& \text { Kriteria : } \\
& \text { - } \mathrm{J}=0 \text { - 0,5 Kemerataan antar }
\end{aligned}
$$

4. Perhitungan Indeks dominansi
Untuk menghitung indeks dominansi dengan menggunakan rumus Simson (Odum, 1996):

$$
\mathrm{C}=\sum(-)^{2}
$$

Keterangan :

$\mathrm{C}=$ indeks Dominansi

$\mathrm{n}_{\mathrm{i}}=$ jumlah individu jenis ke-i

$\mathrm{N}=$ jumlah total individu

Kriteria :

- Nilai C berkisar antara 0 dan 1 , apabila nilai $\mathrm{C}$ mendekati 0 berarti hampirtidak ada individu yang mendominasi

- Nilai C mendekati 1 berarti ada individu yang mendominasi populasi (Odum, 1996).

\section{HASIL DAN PEMBAHASAN}

\subsection{Kondisi Variabel Polutan antar} Lokasi

Hasil Pengukuran empat variabel kualitas air yang digunakan sebagai indikator pencemaran, yaitu: NO3, PO4, Minyak dan POM. Nilai variabel-variabel ini dapat dilihat pada Tabel 2 sebagai berikut.

Tabel 2 Konsentrasi $\mathrm{NO}_{3}, \mathrm{PO}_{4}$, Minyak dan POM pada empat lokasi di Teluk Kupang dan Nilai Baku Mutu masing-masing Parameter

\begin{tabular}{|c|c|c|c|c|c|}
\hline $\begin{array}{c}\text { Kualitas } \\
\text { air }\end{array}$ & Tenau & Kampung solor & Oeba & Lasiana & $\begin{array}{c}\text { Baku } \\
\text { Mutu }\end{array}$ \\
\hline $\mathrm{NO}_{3}$ & $0.1152 \pm 0.0022^{\mathrm{a}}$ & $0.2088 \pm 0.0008^{\mathrm{b}}$ & $0.3901 \pm 0.0023^{\mathrm{c}}$ & $0.2186 \pm 0.0010^{\mathrm{d}}$ & $\leq 0,008$ \\
\hline $\mathrm{PO}_{4}$ & $0.013 \pm 0.0031^{\mathrm{a}}$ & $0.4726 \pm 0.0010^{\mathrm{b}}$ & $0.5654 \pm 0.0029^{\mathrm{c}}$ & $0.0266 \pm 0.0015^{\mathrm{d}}$ & $\leq 0,015$ \\
\hline Minyak & $0.7176 \pm 0.0037^{\mathrm{a}}$ & $0.2472 \pm 0.0016^{\mathrm{b}}$ & $0.0765 \pm 0.0015^{\mathrm{c}}$ & $0.1302 \pm 0.0006^{\mathrm{d}}$ & $\leq 0,3$ \\
\hline POM & $0.0395 \pm 0.0004^{\mathrm{a}}$ & $0.0402 \pm 0.0002^{\mathrm{b}}$ & $0.2316 \pm 0.017^{\mathrm{c}}$ & $0.1492 \pm 0.0016^{\mathrm{d}}$ & \\
\hline
\end{tabular}

$*$ Nilai adalah mean \pm standar deviasi; Superscript yang berbeda pada baris yang sama menunjukan perbedaan nyata $(\mathrm{P}<0,05) ; \mathrm{N}=20$

Anova memperlihatkan bahwa terdapat perbedaan nyata $(\mathrm{P}<0,05)$ dalam kandungan $\mathrm{NO}_{3}, \mathrm{PO}_{4}$, minyak dan $\mathrm{POM}$ antar keempat lokasi. Hasil BNT memperlihatkan bahwa Oeba memiliki kandungan nitrat yang tertinggi 0,3901 $\mathrm{mg} / \mathrm{l}$, lalu diikuti oleh Lasiana 0,2186 $\mathrm{mg} / \mathrm{l}$, Kampung Solor 0,2088 mg/l dan Tenau 0,1152 mg/l. Dari segi Kandungan Fosfat memperlihatkan bahwa Oeba memiliki fosfat yang tertinggi 0.5654 $\mathrm{mg} / \mathrm{l}$, lalu diikuti oleh Kampung Solor $0.4726 \mathrm{mg} / \mathrm{l}$, Lasiana $0.0266 \mathrm{mg} / \mathrm{l}$ dan Tenau $0.013 \mathrm{mg} / \mathrm{l}$. Untuk Kandungan Minyak memperlihatkan bahwa Tenau memiliki kandungan minyak yang tertinggi $0.7176 \mathrm{mg} / \mathrm{l}$, lalu diikuti oleh Kampung Solor $0.2472 \mathrm{mg} / \mathrm{l}$, Lasiana $0.1302 \mathrm{mg} / \mathrm{l}$ dan Oeba 0.0765 mg/l. Dari segi POM memperlihatkan bahwa Oeba memiliki kandungan POM yang tertinggi $0.2316 \mathrm{mg} / \mathrm{l}$, lalu diikuti oleh Lasiana $0.1492 \mathrm{mg} / \mathrm{l}$, Kampung Solor 0.0402 $\mathrm{mg} / \mathrm{l}$ dan Tenau $0.0395 \mathrm{mg} / \mathrm{l}$.

Tabel 2 memperlihatkan bahwa kandungan nitrat yang terukur di keempat lokasi semuanya berada di atas batas baku mutu menurut Kep.No. 51/ MENLH/2004. Untuk kandungan fosfat di perairan Kampung Solor, 
perairan Oeba dan perairan Lasiana memiliki nilai di atas baku mutu. Sedangkan untuk minyak, perairan Tenau memiliki kandungan jauh di atas baku mutu yang ditetapkan. Untuk ketiga lokasi lainnya kandungan minyak belum melampaui batas baku mutu.

Tingginya kandungan fosfat dan nitrat pada perairan intertidal Oeba, diduga disebabkan lokasi perairan intertidalnya berada dekat dengan pemukiman penduduk dan Industri ikan sehingga limbah-limbah domestik yang berasal dari aktivitas pemukiman akan secara langsung masuk kedalam perairan intertidal dan pembuangan sisa-sisa industri ikan yang berada di perairan intertidal Oeba yang kemudian memberi efek pada tingginya kandungan kandungan fosfat, nitrat dan POM di perairan intertidal tersebut. Hal ini didukung oleh Alaerts (1987) dalam Yazwar (2008), yang mengatakan bahwa senyawa fosfat dan nitrat di perairan dipengaruhi oleh limbah penduduk dan limbah industri yang masuk ke dalam perairan.

Tingginya kandungan POM pada perairan intertidal Oeba diduga diakibatkan oleh banyaknya organisme mati yang berasal dari detritus seperti limbah-limbah ikan yang terbuang ke dalam perairan tersebut karena lokasi tersebut berada dekat dengan industri ikan. Selain itu, perairan intertidal di lokasi ini juga mempunyai kedalaman yang rendah sehingga proses dekomposisi berjalan dengan cepat dan mengahasilkan POM yang tinggi. Hal ini sesuai pendapat syam (2002) yang mengatakan bahwa POM di laut meliputi organisme hidup (fitoplankton dan bakteri) dan dektritus (organisme mati). Komposisi dan proporsi dari kedua kelas ini bervariasi sesuai kedalaman dan lokasi.Bagian organisme hidup (karbohidrat dan protein) akan cepat didegradasi (penghilangan POM) serta sebagian kecil detritus. Semakin dalam semakin berkurang karena POM terdekomposisi; Musim : sejalan dengan proses fotosintesa (plankton bloom); Geografis :Pantai : musim semi dan panas (0.3 - $1.2 \mathrm{mg} / \mathrm{l})$, Perairan dangkal $>1 \mathrm{mg}$ /l (sangat produktif). POM di laut meliputi organisme hidup (fitoplankton dan bakteri) dan detritus.

Konsentrasi minyak pada Perairan Tenau sangat tinggi 0,7176 $\mathrm{mg} / \mathrm{l}$, hal ini diduga diakibatkan oleh aktivitas labu kapal dan merupakan tempat lalulitasnya berbagai kapal niaga maupun kapal barang antar kabupaten dan propinsi bahkan antar negara di pelabuhan Tenau. Hal ini sesuai pendapat Castro dan Huber (2007), yang menjelaskan bahwa keberadaan minyak pada suatu ekosistem perairan berasal dari aktivitas labuh kapal, pemanfaatan laut sebagai jalur transportasi, dan penyulingan minyak di daerah pantai. Oleh karena itu dengan bertolak pada pendapat ini maka dapat disimpulkan bahwa lebih tingginya konsentrasi kandungan minyak pada perairan intertidal Tenau dikarenakan lokasi ini merupakan areal pelabuhan, sehingga segala bentuk aktivitas pelabuhan berupa tumpahan minyak dari kapal-kapal yang berlabu di areal tersebut akan secara langsung masuk ke dalam lingkungan perairan.

\subsubsection{Variabel Fitoplankton \\ a. Komposisi Jenis}

Fitoplankton yang ditemukan selama penelitian ditampilkan dalam Tabel 3.

Tabel 3. Komposisi Fitoplankton di perairan intertidal Teluk Kupang

\begin{tabular}{|c|l|c|c|c|c|}
\hline \multirow{2}{*}{ No } & KELAS DIATOM & \multicolumn{4}{|c|}{ LOKASI } \\
\cline { 2 - 6 } & \multicolumn{1}{|c|}{ GENUS } & TENAU & KAMPUNGSOLOR & OEBA & LASIANA \\
\hline 1 & Amphipora & 2 & 22 & 17 & 41 \\
\hline 2 & Amphora & 28 & 8 & 11 & 54 \\
\hline 3 & Ankistrodesmus & 2 & 17 & 76 & 8 \\
\hline 4 & Bacteriastrum & 365 & 153 & 7 & 353 \\
\hline 5 & Biddulphia & 16 & 8 & 3 & 57 \\
\hline 6 & Chaetoceros & 99 & 242 & 76 & 1996 \\
\hline
\end{tabular}




\begin{tabular}{|c|l|c|c|c|c|}
\hline \multirow{2}{*}{ No } & KELAS DIATOM & \multicolumn{4}{|c|}{ LOKASI } \\
\cline { 2 - 6 } & \multicolumn{1}{|c|}{ GENUS } & TENAU & KAMPUNGSOLOR & OEBA & LASIANA \\
\hline 7 & Cocconeis & 15 & 2 & 4 & 86 \\
\hline 8 & Coscinodiscus & 69 & 37 & 73 & 129 \\
\hline 9 & Diploneis & 7 & 4 & 3 & 65 \\
\hline 10 & Guinardia & 2 & 7 & 16 & 156 \\
\hline 11 & Gyrosigma & 6 & 8 & 8 & 30 \\
\hline 12 & Halosphaera & 2 & 3 & 5 & 361 \\
\hline 13 & Hemialus & 8 & 33 & 5 & 49 \\
\hline 14 & Lauderia & 6 & 12 & 52 & 24 \\
\hline 15 & Leptocylindrus & 2 & 106 & 28 & 6 \\
\hline 16 & Lyngbya & 2 & 24 & 375 & 12 \\
\hline 17 & Melosira & 2 & 1349 & 51 & 4 \\
\hline 18 & Navicula & 11 & 26 & 214 & 167 \\
\hline 19 & Nitzschia & 27 & 18 & 88 & 90 \\
\hline 20 & Pelagothrix & 16 & 634 & 10809 & 21 \\
\hline 21 & Planktoniela & 3 & 7 & 24 & 23 \\
\hline 22 & Pleurosigma & 16 & 19 & 100 & 64 \\
\hline 23 & Rhizosolenia & 8 & 42 & 26 & 97 \\
\hline 24 & Streptotheca & 8 & 19 & 34 & 2 \\
\hline 25 & Synedra & 12 & 7 & 32 & 4 \\
\hline 26 & Thalassiosira & 4 & 23 & 23 & 1 \\
\hline 27 & Thalassiotrix & 7 & 4 & 22 & 30 \\
\hline & DINOFLAGELLATA & & & & \\
\hline 28 & Ceratium & 30 & 12 & 15 & 19 \\
\hline 29 & Peridinium & 3 & 16 & 47 & 45 \\
\hline 30 & Stigeoclonium & 3 & 22 & 512 & 4 \\
\hline 31 & Stigonema & 8 & 13 & 1332 & 3 \\
\hline 32 & Surirella & 4 & 17 & 83 & 3 \\
\hline & Kelimpahan $(\mathrm{N})$ & & & & \\
& (Sel/l) & 793 & 2914 & 14171 & 4004 \\
\hline & Keanekaragaman & & & & \\
& (H') & 0,068 & 0,060 & 0,034 & 0,065 \\
\hline & Kemerataan (J') & 1,4 & 0,3 & 0,6 & 0,3 \\
\hline & Dominansi (C) & 0,2 & & & \\
\hline & & & & 599 \\
\hline
\end{tabular}

Tabel 3 memperlihatkan bahwa jenis fitoplankton yang ditemukan di Teluk Kupang terdiri dari 32 genus, tergolong ke dalam kelas Diatom 27 genus dan kelas Dinoflagellta 5 genus. Spesies yang paling banyak ditemui selama penelitian adalah dari genus Pelagothrix, spesies ini termasuk dalam Kelas Diatom.Hal ini sesuai dengan pendapat Nurachmi (2000) yang mengatakan bahwa genus yang paling banyak dijumpai di perairan akibat dari aktifitas manusia adalah dari genus Pelagothtrix, genus Chaetoceros, genus Melosira, dan genus Biddulphia. Selanjutnya Haernina (1987) menyatakan bahwa pada waktu-waktu tertentu populasi suatu jenis fitoplankton dapat tumbuh atau melimpah sehingga muncul jenis yang paling banyak.Munculnya spesies atau populasi ini kadang-kadang dengan tiba-tiba, kemudian hilang lagi dan keberadaannya diganti dengan jenis lainnya.

Beberapa hasil penelitian juga menunjukkan kecenderungan dominansi Diatom dan Dinoflagellata dalam komposisi fitoplankton yang diamati seperti di Perairan Teluk Ambon bagian dalam (Dwiono \& Rahayu, 1984). Penelitian lain oleh Balkis et al. (2004) menemukan bahwa dari 102 taksa fitoplankton yang diidentifikasi di Laut Marmara (Turki), 47 taksa (46,08 \%) 
adalah Diatom dan 45 taksa $(44,12 \%)$ adalah Dinoflagellata.

Menurut

mengatakan

Nybaken

(1992)

dari dua kelas di atas diketahui bahwa kelas diatom mempunyai komposisi genus tertinggi dibandingkan dengan kelas dinoflagellata, dan merupakan sesuatu yang umum dimana kelompokdiatom dan dinoflagellata sering didapatkan dalam jumlah besar dalam penyaringan fitoplankton. Menurut Basmi, 1999 mengatakan bahwa Secara ekologis, diatom merupakan salah satu kelompok algae terpenting yang diperkirakan menghasilkan 40-45 \% produksi primer di laut. Disamping itu, diatom juga tersebar luas pada semua lingkungan akuatik pada semua garis lintang. Menurut Odum (1996), banyaknya kelas diatom di perairan disebabkan oleh kemampuannya beradaptasi dengan lingkungan, bersifat kosmopolit, tahan terhadap kondisi ekstrim serta mempunyai daya reproduksi yang tinggi.

b. Kelimpahan, Keanekaragaman, Kemerataan Jenis dan Dominansi

Kelimpahan, Keanekaragaman, Indeks Kemerataan Jenis dan Dominansi fitoplankton di empat lokasi di Teluk Kupang disajikan dalam Tabel 4 berikut.

Tabel 4. Kelimpahan, Keanekaragaman, Kemerataan Jenis dan Dominansi

\begin{tabular}{|l|l|l|l|l|}
\hline \multicolumn{1}{|c|}{ Indeks } & \multicolumn{1}{|c|}{ Tenau } & \multicolumn{1}{|c|}{ Kampung Solor } & \multicolumn{1}{c|}{ Oeba } & \multicolumn{1}{c|}{ Lasiana } \\
\hline $\begin{array}{l}\text { Kelimpahan (N) } \\
(\text { sel/ L) }\end{array}$ & $793 \pm 40,1098{ }^{a}$ & $2914 \pm 70,8251 \mathrm{~b}$ & $\begin{array}{l}14171 \\
198,0068 \mathrm{c}\end{array}$ & $\begin{array}{l}4004 \\
114,0206 \mathrm{~d}\end{array}$ \\
\hline $\begin{array}{l}\text { Keanekaragaman } \\
\left(\mathrm{H}^{\prime}\right)\end{array}$ & $0,068 \pm 0,0135$ & $0,060 \pm 0,0052$ & $0,034 \pm 0,0076 \mathrm{c}$ & $0,065 \pm 0,102$ \\
\hline $\begin{array}{l}\text { Kemerataan Jenis } \\
(\mathrm{J})\end{array}$ & $1,4 \pm 0,1000 \mathrm{a}$ & $0,9 \pm 0,1581$ & $0,4 \pm 0,1000^{\mathrm{c}}$ & $0,9 \pm 0,2345$ \\
\hline Dominasi (C) & $0,2 \pm 0,0837 \mathrm{a}$ & $0,3 \pm 0,1140$ & $0,6 \pm 0,1140^{c}$ & $0,3 \pm 0,0707$ \\
\hline
\end{tabular}

*Nilai adalah mean \pm standar deviasi; Superscript yang berbeda pada baris yang sama menunjukan perbedaan nyata $(\mathrm{P}<0,05)$; $\mathrm{N}=20$

Kelimpahan Fitoplankton ( N)

Tabel tersebut memperlihatkan bahwa kelimpahan fitoplankton yang tertinggi di perairan Oeba, lalu diikuti Lasiana, Kampung Solor dan Tenau. Hasil Uji BNT memperlihatkan bahwa keempat lokasi di Teluk Kupang memiliki Kelimpahan yang berbeda nyata $(\mathrm{P}<0,05)$ satu sama lain.

Kelimpahan fitoplankton tertinggi ditemukan di perairan intertidal Oeba 14171 sel/l, hal ini diduga disebabkan oleh adanya peningkatan unsur nitrat, fosfat dan POM di perairan tersebut. Hal ini sesuai pendapat Hutabarat dan Evans, (1995) yang menyatakan bahwa fitoplankton bertumbuh pada daerah yang cukup kaya akan bahan-bahan organikdan nutrisi. Hal senada juga dikemukakan oleh Sachlan (1982), bahwa kelimpahan fitoplankton tinggi pada suatu perairan terjadi bila ketersediaan bahan organik juga tinggi. Kelimpahan fitoplankton di Oeba dikategorikan tinggi karena mencapai angka 14171 sel/l. Hal ini sesuai dengan pendapat Sachlan, (1982) dan Prasetyaningtyas., dkk (2012) yang menyatakan bahwa kelimpahan fitoplankton > $12500 \mathrm{sel} / \mathrm{l}$ termasuk kategori tinggi. Sedangkan kelimpahan fitoplankton terendah ditemukan pada perairan intertidal Tenau 793 sel/l,hal ini diduga disebabkan oleh kandungan minyak yang tinggi yang terdapat pada daerah intertidal Tenau sehingga kandungan minyak itu menutupi permukaan air dan menghalangi fotosintesis. Hal ini sesuai dengan pendapat Syam (2002) yang mengatakan bahwa minyak yang tergenang di atas permukaan laut akan menghalangi masuknya sinar matahari ke dalam zona eufotik yang akan menghambat terjadinya proses fotosintesis, sehingga rantai makanan yang berawal pada fitoplankton akan terputus. Hal senada dikemukakan oleh Nurrachmi (2000) dan Makmur (2012) yang menyatakan bahwa populasi fitoplankton senantiasa mengalami fluktuasi dalam komposisi 
dan jumlahnya karena perbedaan kualitas air (terutama unsur hara), juga karena adanya grazing oleh zooplankton dan ikan herbivora serta akumulasi dari sisa-sisa metabolisme yang bersifat toksik. Pendapat yang sama dikemukakan oleh Hutagalung (1990) dan Castro dkk, (2007) yang mengatakan bahwa masuknya minyak dalam suatu perairan dapat memberi pengaruh pada pertumbuhan dan kelangsungan hidup pada seluruh biota atau tumbuhan air yang ada di dalamnya seperti fitoplankton. Pengaruh dari minyak ini dapat bersifat letal (mematikan) dan subletal (mematikan dengan cara tidak langsung). Pengaruh dari kandungan minyak yang bersifat letal adalah dapat membunuh mamalia laut, ikan laut, burung laut, merusak terumbu karang, hutan mangrove, tumbuhan lamun serta dapat mematikan tumbuhan laut lainnya seperti fitoplankton. Sedangkan pengaruh konsentrasi kandungan minyak dalam perairan yang bersifat sub letal yaitu dapat menyebabkan perubahan cara makan, reproduksi, menghambat pertumbuhan fitoplankton dan lain-lain. Hal ini terbukti dari hasil perhitungan kelimpahan fitoplankton yang menunjukkan bahwa perairan intertidal Tenau mempunyai kelimpahan fitoplankton yang rendah.

\section{Keanekaragaman Fitoplankton Shanon Wiener}

Keanekaragaman fitoplankton yang tertinggi di perairan Tenau, lalu diikuti Kampung Solor dan Lasiana sedangkan yang paling rendah adalah Oeba. Hasil Uji BNT memperlihatkan bahwa Oeba memiliki Keanekaragaman yang berbeda nyata $(\mathrm{P}<0,05)$ dengan Tenau, Kampung Solor dan Lasiana. Keanekaragaman tertinggi di Tenau 0,068 dan terendah di Oeba 0,034. Namun secara keseluruhan keanekaragaman fitoplankton keempat lokasi sama-sama rendah karena berkisar pada angka nol. Hal ini diduga disebabkan oleh kualitas air yang tercemar oleh nitrat, fosfat dan minyak. Sesuai pendapat Basmi (1999) yang mengatakan bahwa nilai keanekaragaman fitoplankton kurang dari 1 berarti keanekaragaman spesies rendah, produktivitas rendah, tekanan ekologis yang berat, ekosistem tidak stabil, komunitas biota tidak stabil atau kualitas air tercemar berat. Sehingga dengan mengacu pada pendapat ini maka dapat dikatakan bahwa perairan intertidal Tenau, Kampung Solor, Oeba dan Lasiana keanekaragaman spesies rendah, produktivitas rendah, tekanan ekologis yang berat, ekosistem tidak stabil, komunitas biota tidak stabil dan kualitas air tercemar berat.

\section{Kemerataan Jenis Fitoplankton (J) (Pilou)}

Kemerataan jenis fitoplankton yang tertinggi diperairan Tenau, diikuti Kampung Solor dan Lasiana sedangkan yang terendah yaitu Oeba. Hasil Uji BNT memperlihatkan bahwa keempat lokasi memiliki Kemerataan Jenis yang berbeda nyata $\quad(\mathrm{P}<0,05)$ satu sama lain. Kemerataan Jenis yang tertinggi di Tenau 1,4, diikuti Kampung Solor 0,9, Lasiana 0,9 dan terendah di Oeba 0,4. Menurut Odum (1996) dalam Basmi (1999), Kemerataaan individu suatu biota yaitu 0-0,5 (kemerataan antar individu rendah) artinya kekayaan individu yang dimiliki masing-masing spesies sangat jauh berbeda atau tidak seragam, dan kemerataan individu biota 0,6-1 (Kemerataan individu relatif seragam atau jumlah individu masing-masing spesies relatif sama). Jika merujuk pada pendapat ini dengan melihat angka Kemerataan Jenis di perairan Oeba 0,4 maka dapat disimpulkan bahwa fitoplankton pada perairan intertidal Oeba kemerataan Jenis rendah, kekayaan individu yang dimiliki masing-masing spesies sangat jauh berbeda atau relatif tidak seragam. Sedangkan Kemerataan Jenis di perairan Tenau 1,4, Kampung Solor 0,9, dan Lasiana 0,9 maka dapat disimpulkan bahwa fitoplankton pada perairan Tenau, Kampung Solor dan Lasiana memiliki nilai Kemerataaan Jenis yang tinggi, sehingga Kemerataan individu relatif seragam atau jumlah individu masing-masing spesies relatif sama.

Dominasi Fitoplankton (C) 
Untuk Dominasi fitoplankton yang tertinggi di Oeba, diikuti oleh Lasiana dan Kampung Solor, sedangkan yang terendah yaitu Tenau. Hasil Uji BNT memperlihatkan bahwa keempat lokasi memiliki Dominasi yang berbeda nyata $(\mathrm{P}<0,05)$ satu sama lain. Dominasi fitoplankton tertinggi terdapat di perairan intertidal Oeba 0,60 , diikuti Kampung Solor 0,30, Lasiana 0,30dan terendah terdapat di perairan intertidal Tenau 0,20. Odum (1996) dalam Basmi (1999), mengemukakan bahwa Nilai C (indeks dominasi) berkisar antara 0 dan 1, apabila nilai $\mathrm{C}$ mendekati 0 berarti hampir tidak ada individu yang mendominasi, sedangkan bila C mendekati 1 berarti ada individu yang mendominasi populasi. Berdasarkan nilai indeks dominasi keempat lokasi penelitian, diketahui bahwa nilai dominasi dari perairan intertidal Oeba 0,60 yaitu berada pada kisaran yang melebihi nilai 0 sampai mendekati nilai 1 . Dengan demikian maka dapat dikatakan bahwa pada perairan intertidal Oeba ada individu fitoplankton yang lebih mendominasi populasi fitoplankton yang ada. Sedangkan di perairan intertidal Tenau, Kampung Solor, dan Lasiana, Kondisi nilai indeks dominansinya mendekati 0, maka dapat dikatakan bahwa perairan Tenau, Kampung Solor dan Lasinana belum ada individu yang dominan pada perairan tersebut. Tingginya Dominasi individu fitoplankton di Perairan Oeba diduga disebabkan oleh limbah domestik dan limbah industri akibat dari aktivitas masyarakat yang tinggi. Hal ini sesuai dengan pendapat Nurrachmi (2000) menambahkan genus yang paling banyak dijumpai di perairan akibat dari aktifitas manusia adalah dari genus Pelagothtrix, genus Chaetoceros, genus Melosira, dan genus Biddulphi.Hal senada dikatakan oleh Haernina (1987) bahwa pada waktu-waktu tertentu populasi suatu jenis fitoplankton dapat tumbuh atau melimpah sehingga muncul jenis yang paling banyak. Munculnya spesies atau populasi ini kadang-kadang dengan tiba-tiba, kemudian hilang lagi dan keberadaannya diganti dengan jenis lainnya.

\subsubsection{Korelasi antara Variabel Polutan dan Variabel Fitoplankton}

Hasil analisis Korelasi Pearson antara variabel polutan $\left(\mathrm{NO}_{3}, \mathrm{PO}_{4}\right.$, Minyak dan POM) dan variabel fitoplankton (Kelimpahan, Keanekaragaman, Kemerataan dan Dominansi) ditampilkan dalam Tabel 5.

\section{Tabel 5 Nilai Korelasi Pearson antara variabel Polutan dan variabel Fitoplankton}

\begin{tabular}{|c|c|c|c|c|}
\hline Variabel Polutan & \multirow[b]{2}{*}{$\mathrm{NO}_{3}$} & \multirow[b]{2}{*}{$\mathrm{PO}_{4}$} & \multirow[b]{2}{*}{ Minyak } & \multirow[b]{2}{*}{$\mathrm{POM}$} \\
\hline $\begin{array}{l}\text { Variabel } \\
\text { Fitoplankton }\end{array}$ & & & & \\
\hline $\begin{array}{l}\text { Kelimpahan }(\mathrm{N}) \\
\text { (sel/L) }\end{array}$ & $0,812^{* *}$ & $0,692^{* *}$ & $-0,671^{* *}$ & $0,902^{* *}$ \\
\hline $\begin{array}{l}\text { Keanekaragaman } \\
\left(\mathrm{H}^{\prime}\right)\end{array}$ & ${ }^{-}, \overline{772} 2^{* *}$ & $\begin{array}{c}- \\
0,682^{* *}\end{array}$ & $0,511^{*}$ & $\stackrel{-}{-} 672^{* *}$ \\
\hline $\begin{array}{l}\text { Kemerataan } \\
\text { Jenis }(J)\end{array}$ & $0,663^{* *}$ & $0,720^{* *}$ & $0,832^{* *}$ & $0,782^{* *}$ \\
\hline Dominasi (C) & $0,710^{* *}$ & $0,708^{* *}$ & $-0,664^{* *}$ & $0,691^{* *}$ \\
\hline
\end{tabular}

Tabel 5 menunjukan bahwa semua variabel polutan $\left(\mathrm{NO}_{3}, \mathrm{PO}_{4}\right.$, Minyak dan POM) berkorelasi nyata dengan indeks fitoplankton (kelimpahan, keanekaragaman, kemerataan jenis dan dominansi $\mathrm{P}<0,05$ ).

Kelimpahan fitoplankton berkorelasi positif dengan $\mathrm{NO}_{3}, \mathrm{PO}_{4}$, dan POM akan tetapi tingginya kandungan minyak menyebabkan rendahnya kelimpahan fitoplankton. Menurut Jhon, dkk., (2002), mengatakan bahwa tingginya nutrien (nitrat, fosfat dan POM) di perairan akan mempengaruhi tingginya kelimpahan fitoplanton. Hal yang sama dikatakan oleh Kamali (2004) bahwa Kelimpahan fitoplankton memiliki hubungan positif dengan kesuburan perairan. Apabila kelimpahan fitoplankton di suatu perairan tinggi maka perairan tersebut cenderung memiliki produktifitas yang tinggi pula. Sedangkan menurut Basmi (1999) mengatakan bahwa minyak yang tinggi diperairan dapat memberikan tekanan ekologis yang berat dan mengakibatkan ekosistem tidak stabil sehingga berakibat pada rendahnya kelimpahan fitoplankton. Nilai keanekaragaman fitoplankton berkorelasi positif dengan minyak akan tetapi berkorelasi negatif 
dengan $\mathrm{NO}_{3}, \mathrm{PO}_{4}$, dan $\mathrm{POM}$. Nilai keanekaragaman fitoplankton yang tinggi maka nilai kemerataan jenis pun tinggi, sedangkan nilai kelimpahan dan nilai dominansinya menjadi menurun. Hal ini sesuai dengan pendapat Haernina (1987) yang mengatakan bahwa nilai keanekaragaman fitoplankton yang tinggi akan diikuti dengan tingginya nilai kemerataan, akan tetapi nilai kelimpahan dan nilai dominansi fitoplankton akan berkurang.

Nilai Kemerataan jenis fitoplankton berkorelasi positif dengan minyak namun berkorelasi negatif dengan $\mathrm{NO}_{3}, \mathrm{PO}_{4}$, dan $\mathrm{POM}$. Hal ini sesuai dengan pendapat Jhon, dkk., (2002) yang mengatakan bahwa menurunnya nilai Kemerataan Jenis fitoplankton akan diikuti dengan menurunnya keanekaragaman fitoplankton namun nilai kelimpahan dan dominansi fitoplankton tinggi. Dominansi

fitoplankton berkorelasi positif dengan kandungan $\mathrm{NO}_{3}, \mathrm{PO}_{4}$, dan $\mathrm{POM}$ tetapi berkorelasi negatif dengan minyak. Hal ini sesuai dengan pendapat Jhon, dkk., (2002) yang mengatakan bahwa tingginya nilai dominansi fitoplankton di perairan, akan diikuti dengan tingginya kelimpahan fitoplankton tetapi keanekaragaman dan kemerataan jenisnya akan menurun.

\subsubsection{Species Fitoplankton yang Dominan antar Jenis Polutan}

Tabel 6. Tiga Species yang memiliki Kelimpahan Tertinggi di masingmasing variabel kualitas air yang dominan di empat lokasi di Teluk Kupang

\begin{tabular}{|l|c|c|c|c|}
\hline Kelas/ Species & $\mathrm{NO}_{3}$ & $\mathrm{PO}_{4}$ & Minyak & $\mathrm{POM}$ \\
\hline Diatom & & & & \\
\hline Pelagothrix & & $\mathrm{P}$ & & \\
\hline Bacteriastrum & & & $\mathrm{P}$ & \\
\hline Coscinodiscus & & & $\mathrm{P}$ & \\
\hline Melosira & & $\mathrm{P}$ & & \\
\hline Chaetoceros & $\mathrm{P}$ & & & \\
\hline Leptocylindrus & & & $\mathrm{P}$ & \\
\hline Halosphaera & & & & $\mathrm{P}$ \\
\hline Navicula & & & & $\mathrm{P}$ \\
\hline Lyngbya & $\mathrm{P}$ & & & \\
\hline Dinoflagelata & & & & \\
\hline Stigonema & & $\mathrm{P}$ & & \\
\hline
\end{tabular}

\begin{tabular}{|l|c|c|c|c|}
\hline Kelas/ Species & $\mathrm{NO}_{3}$ & $\mathrm{PO}_{4}$ & Minyak & POM \\
\hline Stigeocl onium & $\mathrm{P}$ & & & \\
\hline Rhizosolenia & & & & $\mathrm{P}$ \\
\hline
\end{tabular}

Tabel 6 memperlihatkan bahwa species-species dari kelas Diatom dominan diperairan yang mengandung nitrat, Fosfat, minyak dan POM. Sedangkan species-species dari kelas Dinoflagellata banyak terdapat di perairan yang mengandung Nitrat, $\mathrm{PO}_{4}$ dan POM. Tiga species utama di perairan yang mengandung nitrat yang tinggi yaitu: Species Chaetoceros, Lyngbyadan Stigeoclonium. Tiga species utama di perairan yang mengandung fosfat yang tinggi yaitu: Pelagothrix, Melosira, dan Stigonema. TigaSpeciesutama di perairan yang mengandung POM yang tinggi yaitu: Halosphaera, Navicula dan Rhizosolenia. Sedangkan Tiga species utama di perairan yang mengandung minyak yang tinggi yaitu: Bacteriastrum, Coscinodiscus dan Leptocylindrus. Tiga species yang memiliki kelimpahan tertinggi pada variabel-variabel kualitas air yang dominan diduga disebabkan karna ada beberapa fitoplankton yang dapat bertahan pada kondisi air yang tercemar. Hal ini sesuai dengan pendapat Jhon,dkk, 2000 yang mengatakan bahwa beberapa fitoplankton seperti : Pelagothrix, Ceratium, Bacteriastrum, Navicula, Bacteriastrum, Coscinodiscus, Ceratium dan Chaetoceros merupakan spesies fitoplankton yang mampu bertahan pada kondisi tercemar. Ketiga species tersebut mampu melindungi dirinya dari zat-zat beracun yang berada di perairan dengan adanya protective cyste. Oleh karena itu, species-species tersebut mampu hidup pada perairan yang mengalami pencemaran limbah organik dan minyak.Hal senada dikatakan Haumahu, (2004) dan Kingsford, (2000) bahwa Fitoplankton yang menjadi indikator pencemaran bahan organik dalam perairan yaitu : Phormodium,Melosira, Chaetoceros, Leptocylindrus, Halosphaera, Navicula, Coscinodiscus, Stigonema, Stigeoclonium, Ceratium, dan Pelagothrix.

\section{KESIMPULAN}


Berdasarkan uraian hasil dan pembahasan di atas maka dapat disimpulkan bahwa :

1. Terdapat perbedaan kandungan polutan $\mathrm{NO}_{3}, \mathrm{PO}_{4}$, minyak dan $\mathrm{POM}$ antar lokasi di Teluk Kupang. Kandungan Nitrat yang tertinggi terdapat di Oeba, lalu diikuti oleh Lasiana, Kampung Solor dan Tenau. Dari segi Kandungan Fosfat memperlihatkan bahwa Oeba memiliki fosfat yang tertinggi, lalu diikuti oleh Kampung Solor, Lasianadan Tenau. Untuk Kandungan Minyak memperlihatkan bahwa Tenau memiliki kandungan minyak yang tertinggi, lalu diikuti oleh Kampung Solor, Lasiana dan Oeba. Dari segi POM memperlihatkan bahwa Oeba memiliki kandungan POM yang tertinggi, lalu diikuti oleh Lasiana, Kampung Solor dan Tenau.

2. Terdapat perbedaan nilai kelimpahan, keanekaragaman, kemerataan jenis dan dominansi di setiap lokasi penelitian. Indeks Kelimpahan fitoplankton tertinggi berada pada perairan intertidal Oeba $14171 \mathrm{sel} / \mathrm{l}$, sedangkan terendah berada pada perairan intertidal Tenau $793 \mathrm{sel} / \mathrm{l}$. Kelimpahan fitoplankton tertinggi di Oeba diakibatkan oleh tingginya kandungan nitrat, fosfat dan POM. Sedangkan rendahnya kelimpahan Fitoplankton di Tenau diakibatkan oleh tingginya kandungan minyak di perairan Tenau.

Indeks Keanekaragaman fitoplankton tertinggi di Perairan intertidal Tenau 0,068 sedangkan terendah di perairan Oeba 0,034. Namun secara umum Keanekaragaman fitoplankton keempat lokasi rendah yaitu berkisar pada angka nol yang artinya kualitas air tercemar berat. Indeks Kemerataan Jenis yang tertinggi di Tenau 1,4 diikuti Kampung Solor 0,9, Lasiana 0,9 dan terendah di Oeba 0,4. Tenau, Kampung Solor dan Lasiana Kemerataan individu relatif seragam atau jumlah individu masing-masing spesies relatif sama. Sedangkan di Oeba Kemerataan antar individu rendah, artinya kekayaan individu yang dimiliki masing-masing spesies sangat jauh berbeda. Dominansi fitoplankton yang tertinggi di Oeba 0,6 diikuti oleh Lasiana 0,3 dan Kampung Solor 0,3 artinya : di perairan intertidal Tenau, Kampung Solor dan Lasiana belum ada individu yang dominan sedangkan yang terendah yaitu Tenau 0,2 artinya: Perairan intertidal Oeba ada individu fitoplankton yang lebih mendominasi populasi fitoplankton yang ada.

3. Adanya korelasi yang kuat antara variabel fitoplankton dengan variable jenis polutan di setiap lokasi peneltian. Kelimpahan fitoplankton berkorelasi positif dengan kandungan nitrat, fosfat dan POM tetapi kelimpahan berkorelasi negatif dengan minyak. Sedangkan Keanekaragaman berkorelasi negatif dengan nitrat, fosfat dan POM tetapi berkorelasi positif dengan minyak. Kemerataan jenis berkorelasi negatif dengan nitrat, fosfat dan POM sedangkan Kemerataan jenis berkorelasi Positif dengan minyak. Dominasi fitoplankton berkorelasi positif dengan kandungan nitrat, fosfat dan POM tetapi berkorelasi negatif dengan minyak.

\section{DAFTAR PUSTAKA}

Alaerts, G \& Sri, 1987. Metode Penelitian Air. Usaha Nasional, Surabaya

Bait, N.M, 2011. Analisis Ekologis Mmangrove di Desa Bipolo Kecamatan Selamu Kabupaten Kupang (Tesis). Program Pascasarjana Undana Kupang.

Balkis, N., B. Ergor \& M. Giresunlu. 2004. Summer phytoplankton composition in the neritic waters of the Sea of Marmara. Pakistan Journal of Botany, 36(1): 115-126

Basmi, S. 1999. Ekologi Plankton I. Fakultas Pertanian IPB . Bogor

Castro, P., M. Huber, 2007. Marine Biology.7th ed. McGraw-Hill Companies Inc., New York: xix + $459 \mathrm{hlm}$.

Dwiono, S.A.P \& D.L. Rahayu. 1984. Studi pendahuluan fitoplankton di Teluk Ambon bagian dalam. Oseanologi di Indonesia, 18: 5561. 
Haernina, E. 1987. Komposisi dan Distribusi Vertikal Harian Fitoplankton Pada Siang dan Malam Hari di Perairan Pantai Bojonegoro, Teluk Banten. Jurnal. Fakultas Perikanan Bogor. IPB

Haumahu, S. 2004. Distribusi spasial fitoplankton di Teluk Ambon bagian dalam.Ichthyos, 3(2): 9198.

Hutagalung, H. P. dan A. Rozak. 1997. Metode Analisis Air Laut, Sedimen dan Biota. Buku 2. LIPI. Jakarta. 182 hal

Hutabarat S. Evans SM. 1995. Pengantar Oceanografi. Universitas Indonesia Press, Jakarta

Jhon, D.M.,B.A. Whitton \& A.J.Brook. 2002. The Freshwater Algal Flora of The British Isles. The United Kingdom at the University Press, Cambridge.

Jumini, 2011. Hubungan antara Struktur Komunitas Padang Lamun dengan keanekaragaman Makrobentos di di perairan Tablolong dan Paradiso Kupang (Tesis). Program Pascasarja Undana Kupang.

Kep MENLH. 2004. Keputusan Kantor Menteri Negara Lingkungan Hidup No.Kep 51 / MENLH / I / 2004. Tentang Pedoman Penetapan Baku Mutu Lingkungan. 11 hal.

Kamali. 2004. Komunitas Fitoplankton. Istitut Pertanian Bogor. Bogor

Kingsford, M.J. 2000. Planktonic processes. In: A.J. Underwood \& M.G. Chapman (Eds.). Coastal Marine Ecology of Temperate Australia. University of New South Wales Press Ltd, Sydney: 28-41

Mas'ulah, R, 2011. Keterkaitan antara Struktur Komunitas Lamun dan Struktur Populasi Bulu Babi pada Zona Intertidal di Desa Bolok, Kabupaten Kupang (Tesis). Program Pascasarjana Undana Kupang.

Makmur, M., Kusnoputranto, H., Moersidik, S.S., Wisnubroto, S.D. 2012. Pengaruh Limbah Organik \& Rasio N/P Terhadap Kelimpahan Fitoplankton Di
Kawasan Budidaya Kerang Hijau Cilincing. BATAN

Nybakken, J. W.1992. Biologi Laut : Suatu Pendekatan Ekologis. Diterjemaahkan oleh H. M. Eidman, Koesoebiono, D. G. Bengen, M. PT Gramedia. Jakarta

Nurrachmi, I. 2000. Hubungan konsentrasi Nitrat dan Fosfat dengan kelimpahan Diatom (Bacillariophyceae) di perairan pantai Dumai Barat. J. Perikanan dan Kelautan 4(12): 47-58

Odum, E. P, 1996. Dasar-dasar Ekologi. Diterjemahkan oleh Samingan, T. Dan Sri Gandono,B. Cet-3.Gajah Mada Press. IKAPI. Yogyakarta. $571 \mathrm{p}$.

Prasetyaningtyas T, Priyono B, Agung T. 2012. Keanekaragaman Plankton di Perairan Tambak Ikan Bandeng di Tapak Tugurejo, Semarang. Jurnal. UNS. Semarang.

Romimohtarto, K., Juwana, S. 2007. Biologi Laut : Ilmu Pengetahuan Tentang Biota Laut. Penerbit Djambatan, Jakarta. Ed. Rev.,cet. Ke-3. Hal. 321-332.

Rusydi, Barhiman, A. Majid, F.J.L Risamasu, dan T. Da Cunha, 2010. Baseline Data Kualitas Air dan Biota Perairan di Teluk Kupang Sebelum Pengoperasian PLTU di Bolok Kecamatan Kupang Barat. Kerjasama Fakultas Perikanan UMK dan PT TOM Kupang.

Sachlan, M. 1982. Planktonologi.Fakultas Peternakan dan Perikanan. Undip, Semarang.

Sine, K.G, 2012. Fitoplankton sebagai Bioindikator Kondisi Terumbu Karang di Perairan Teluk Kupang dan Sekitarnya (Tesis). Program Pascasarjana Undana, Kupang.

Syam, A.R. 2002. Produktivitas Primer Fitoplankton dan Perbandingan Beberapa Karakteristik Biofisikimia Perairan Teluk Jakarta dan Teluk Lampung. Program Pascasarjana. IPB. Bogor. $128 \mathrm{hal}$

Yamaji, I. 1984. Illustration of The Marine Plankton of Japan. Hoikusha Publishing Co., Ltd. : Osaka. Japan 
Yazwar, 2008. Keanekaragaman Plankton dan Keterkaitannya dengan Kualitas Air di Parapat Danau
Toba. Tesis. Sekolah Pascasarjana. Universitas Sumatra Utara. Medan 